\title{
The use of Bayesian design in two trials in rare cancers
}

\author{
Peter Dutton ${ }^{1,2^{*}}$, Sharon Love ${ }^{1,2}$, Ade Faleti ${ }^{3}$, Bass Hassan ${ }^{2,4}$ \\ From 3rd International Clinical Trials Methodology Conference \\ Glasgow, UK. 16-17 November 2015
}

Trials run in either rare diseases or rare subpopulations of common diseases are challenging in terms of identifying, recruiting and completing sufficient patients in a sensible time period. Moreover, the increasing emphasis on personalised and precision criteria for selection and endpoints during early drug development is changing the demands on trial designs because of a more limited number of patients.

We will discuss two active trials in bone sarcoma which use Bayesian methodologies. In designing these trials we needed to minimise the expected sample size whilst having acceptable properties. To do this a number of Frequentist and Bayesian approaches were considered and compare using Frequentist and Bayesian properties.

In the MEMOS trial, adaptations to Simon's two stage design to allow stopping early for efficacy and a Bayesian posterior predictive solution provide an efficient trial design.

In the LINES trial, a Bayesian posterior predictive approach allows co-primary endpoints to be accounted for effectively in this single arm trial. The results of the first interim analysis will be described.

\section{Funding}

The research leading to these results has received funding from the European Union Seventh Framework Programme (FP7/2007-2013) under grant agreement $n$ - 278742 (Eurosarc), NIHR funding from BRC and BRU and CRUK funding.

\footnotetext{
Authors' details

${ }^{1}$ Centre for Statistics in Medicine, University of Oxford, Oxford, UK. ${ }^{2}$ NDORMS,
} Oxford, UK. ${ }^{3}$ OCTO, Oxford, UK. ${ }^{4}$ OMPI, SWDS, Oxford, UK.

Published: 16 November 2015

${ }^{1}$ Centre for Statistics in Medicine, University of Oxford, Oxford, UK Full list of author information is available at the end of the article
doi:10.1186/1745-6215-16-S2-P213

Cite this article as: Dutton et al:: The use of Bayesian design in two trials in rare cancers. Trials 2015 16(Suppl 2):P213.
Submit your next manuscript to BioMed Central and take full advantage of:

- Convenient online submission

- Thorough peer review

- No space constraints or color figure charges

- Immediate publication on acceptance

- Inclusion in PubMed, CAS, Scopus and Google Scholar

- Research which is freely available for redistribution

Submit your manuscript at www.biomedcentral.com/submit
C Biomed Central

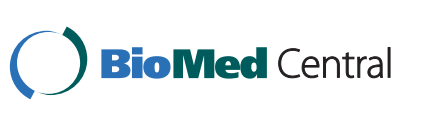

(c) 2015 Dutton et al. This is an Open Access article distributed under the terms of the Creative Commons Attribution License (http:// creativecommons.org/licenses/by/4.0), which permits unrestricted use, distribution, and reproduction in any medium, provided the original work is properly cited. The Creative Commons Public Domain Dedication waiver (http://creativecommons.org/publicdomain/ zero/1.0/) applies to the data made available in this article, unless otherwise stated. 